\title{
Karbonmonoksit İntoksikasyon Tanısı ile Yoğunbakımda Tedavi Edilen Olguların Retrospektif Analizi
}

\author{
Carbon Monoxide Intoxication Treatment in Intensive Care; \\ Retrospective Analysis of the Cases
}

\author{
${ }^{1}$ Gülçin Aydın, ${ }^{1}$ Işın Gençay, ${ }^{2}$ Selim Çolak, ${ }^{3}$ Burak Aktan, ${ }^{4}$ Ünase Büyükkoçak \\ ${ }^{1}$ Kırıkkale Üniversitesi Tıp Fakültesi, Anesteziyoloji ve Reanimasyon Anabilim Dalı, Kırıkkale, Türkiye \\ ${ }^{2}$ Ankara Özel Etimed Hastanesi Anesteziyoloji ve Reanimasyon Anabilim dal, Ankara, Türkiye \\ ${ }^{3}$ Bingöl Kadın Doğum ve Çocuk Hastanesi Anesteziyoloji ve Reanimasyon Anabilim dalı, \\ Bingöl, Türkiye \\ ${ }^{4}$ Yüksek İhtisas Üniversitesi Koru Hastanesi Anesteziyoloji ve Reanimasyon Anabilim Dalı, \\ Ankara, Türkiye
}

\begin{abstract}
Özet: Bu çalışmanın amacı karbon monoksit intoksikasyon tanılı hastaların etyolojik ve demografik özelliklerini belirlerken, klinik bulguların tedavi sürecine ve prognoza etkisini araştırmaktır. Çalısmaya 2014-2017 yılları arasında Yoğun Bakım Ünitemizde karbon monoksit intoksikasyon tanısı ile yatan 63 hasta dahil edildi. Yaş ortalaması 44.49 yıl olan hastaların 32'si kadın, 31'i erkek idi. Maruziyet sonrası acil servise başvuru süresi ortalama 6.22 saat idi. Başvuru anında COHb değeri ortalama \%27 idi. En sık maruziyet \%61.9 ile kış mevsiminde iken en sık maruziyet kaynağ $\% 93.7$ ile soba idi. Acil servise başvuru anında ortalama GKS puanı 14.1 puan idi. Hastaların \%79.4'ünde nöropsikiyatrik semptomlar, \%36.5'inde gastrointestinal semptomlar, \%23.8'inde solunum sistemi semptomları, \%15.9'unda otolojik semptomlar, \%11.1'inde ise kardiyovasküler semptomlar vardı. İki hastada mekanik ventilatör, 57 hastada noninvazif mekanik ventilatör (NIMV) ve 12 hastada hiperbarik oksijen tedavisi ihtiyacı oldu. Hastaların çıkış GKS değerleri ortalama 15 idi. Hastanede ortalama yatışs süreleri 1.71 gün idi. Hastalar başvuru anındaki COHb düzeylerine göre; COHb düzeyi $\% 10$ 'nun altında hafif (grup 1), \%11-25 arası orta (grup 2), \%26-40 arası ağır (grup 3), \%41 üzeri çok ağır (grup 4) olarak gruplandırıldı. Gruplar arasında $\mathrm{pH}$, GKS gelis puanı, otolojik semptomlar, NIMV ihtiyacı, SpO2, CK-CKMB düzeyi değerleri arasında istatistiksel olarak anlamlı fark bulundu. Hastalar hastaneye başvuru anındaki GKS puanlarına göre grup A (GKS=15) ve grup B (GKS $<15)$ olarak sınıflandırıldı. gruplar arasında; $\mathrm{COHb}$ geliş düzeyi, KVS semptomlar, ek hastalık varlığı, solunum sistemi semptomları, mekanik ventilatör ihtiyacı, HBO ihtiyacı, CK ve troponin düzeyi açısından istatistiki olarak anlamlı fark vardı. Hiperbarik oksijen tedavisi alan (grup I) ve almayan (grup II) hastalar da karşıllaştırmalı olarak değerlendirildi. grup I'de troponin-I ( $\mathrm{p}=0.015), \mathrm{CK}(\mathrm{p}=0.032)$ düzeylerinde ve mekanik ventilasyon ihtiyacında ( $\mathrm{p}=0.003)$ belirgin artış olduğu, GKS'nun düsük olduğu $(\mathrm{p}<0.001)$ tespit edildi. Bununla birlikte HBO tedavisi gereksinimi ile troponin ve CK seviyesi arasında pozitif yönde korelasyon olduğu görüldü. Bu çalışma sonunda karbon monoksit intoksikasyon tanılı hastalarda başvuru anındaki GKS puanı, COHb, CK-CKMB ve laktat değerlerinin klinik bulgular ile birlikte yorumlanmasının hem tedavi hem de prognoz üzerinde önemli etkilerinin olabileceği düşünüldü. Anahtar Kelimeler: karbonmonoksit intoksikasyonu, karboksihemoglobin, hiperbarik oksijen tedavisi.
\end{abstract}

Abstract: In this study, we aimed to determine the etiological and demographic characteristics of patients with carbon monoxide intoxication to reveal their relationship with the clinical findings, and to investigate the treatment processes and prognoses of these patients. A total of 63 patients diagnosed with carbon monoxide intoxication and hospitalized in the Department of Anesthesiology and Reanimation Intensive Care Unit between 2014 and 2017. The age avarage of the patients was 44.9 years. 32 patients were female and 31 patients were male. The avarage duration between exposion and reffering to emergency department was 6.22 hours. Initial $\mathrm{COHb}$ value avarage was $27 \%$. Most common exposion to carbonmonoxide was $61,9 \%$ winter and common source of exposion was $93,7 \%$ heating stove. Avarage GCS at emergency admission was 14.1 . Neuropsychiatric symptoms were observed in $79.4 \%$, gastointestinal symptoms were observed in $36.5 \%$, respiratory symptoms were observed in $15.9 \%$ and cardiovascular symptıms were observed in $11.1 \%$ of the patients. Two patients required mechanical ventilation, 57 patients required noinvasive mechanical ventilation (NIMV) and 12 patients required hyperbaric oxygen (HBO) treatment. The avarage of GCS at discharge was 15 . Hospital stay duration avarage was 1.71 days. Patients were divided into three groups according to their COHb levels at admission, COHb levels under $10 \%$ mild (Group 1), between 11-25\% intermediate (Group 2), between 26-45\% serious (Group 3) and over $41 \%$ very serious (Group 4). There were statistically significant difference between groups in means of $\mathrm{pH}$ levels, admission GCS, otologic symptoms, NIMV requirement, SpO2 levels and CK, CK-MB levels. Patient were also divided into two groups according to their GCS scores at admission, Group A (GCS=15) and Group B $(<15)$. There were statistically significant difference between groups in means of $\mathrm{COHb}$ levels at admission, cardiovascular symptoms, presence of comorbidities, respiratory symptoms, HBO requirement, $\mathrm{CK}$ and troponin levels and mechanical ventilation requirement. Patients who had $\mathrm{HBO}$ treatment (Group I) and who had not hyperbaric oxygen treatment (Group II) were comperatively evaluated. Troponin-I $(\mathrm{p}=0,015), \mathrm{CK}(\mathrm{P}=0,032)$ levels and mechanical ventilation requirement $(p=0,003)$ were significantly higher but GCS scores $(p<0,001)$ were significantly lower at Group I. At the same time a significant positive corelation between HBO treatment requirement and troponin,CK levels was found. As a result, management of the patients that diagnosed as carbon monoxide intoxication along with GCS scores at admission, COHb, CK,CK-MB and lactate levels is very important effects on prognosis and treatment of the patients.

Keywords: carbon monoxide intoxication, carboxyhemoglobin, hyperbaric oxygen therapy

ORCID ID of the authors: G.A. 0000-0001-9672-7666, I.G. 0000-0001-5279-9975, S.Ç. 0000-0002-8364-982X, B.A. 0000-0003-4175-3319,Ü.B. 0000-0001-8472-6041

Received 12.09.2018

Accepted 15.11.2018

Online published 16.11 .2018

Correspondence: Gülçin AYDIN- Kırıkkale Üniversitesi Tıp Fakültesi Anesteziyoloji ve Reanimasyon Anabilimdalı, Kırıkkale, Turkey,

e-mail: drgulcinaydin@yahoo.com 


\section{Giriş}

Karbonmonoksit (CO) tatsız, kokusuz, tahriş edici olmayan ama son derece zehirli bir gaz olup çoğunlukla yangın öyküsü, mesleki maruziyet ve isınma sonrası intoksikasyona neden olabilmektedir (1). Karbon monoksit intoksikasyonlarının (COI) semptomları nonspesifik olup genelde başağrısı, miyalji, baş dönmesi, konfüzyon, bilinç kaybı ve ölüm gibi geniş bir yelpaze ile kendini gösterir. $\mathrm{Bu}$ durumdan bütün organlar zarar görebilirken en fazla etkilenen organların beyin ve kalp olduğu rapor edilmektedir (2).

Gelişmekte olan ülkeler için kışın kullanılan mangal, soba, kömür kazanı gibi ısınma araçlarından sızabilen CO gazı ile olan zehirlenmeler önemli bir sorun teşkil etmektedir. Ülkemizde de halen bu durum ciddi bir halk sağlığı sorunu olmaya devam etmektedir.

$\mathrm{Bu}$ çalışma ile COİ tanılı hastaların etyolojik ve demografik özelliklerini belirlemek ve acil servise başvuru anındaki semptomları, $\mathrm{COHb}$ düzeyleri, GKS puanlarının yoğun bakım tedavi süreçleri ve prognozlarına etkisini araştırmak amaçlanmıştır.

\section{Gereç Yöntem}

Çalışmaya 2014-2017 yılları arasında Anesteziyoloji ve Reanimasyon Yoğun Bakım Ünitesine (YBÜ) yatı̧ıı yapılan ve öykülerinde CO kaynağına maruz kalarak zehirlenme bulgular1 olup, karbonmonoksit oksimetre cihazı (Masimo Rad 57) ile ölçülen $\mathrm{COHb}$ miktarının $\% 5$ 'in üzerinde olan hastalar dahil edildi. Çalışma için etik kurulu onay1 alınd1 (16.05.2017; 12/17). Hastaların tıbbi kayıtlarında yer alan yaş, cinsiyet, $\mathrm{CO}$ maruziyet kaynağ 1 , mevsimsel durum, acil servise başvurma süreleri, acil servise geliş GKS puanı ve klinik bulguları, geliş arteryal kan gazı ve $\mathrm{COHb}$ değerleri, kan hemoglobin $(\mathrm{Hb})$, serum troponin, kreatin kinaz (CK), kreatin kinaz-MB (CK-MB) ve laktat düzeyleri, klinik bulguları, elektrokardiyografi (EKG) bulguları, ek hastalık varlığı, yoğun bakımda yatış süreleri, mekanik ventilatör ihtiyaçları, hiperbarik oksijen (HBO) tedavi gereksinimleri değerlendirildi. Hastalar başvuru anındaki $\mathrm{COHb}$ düzeylerine göre 4 gruba ayrıldı. COHb düzeyi \%10'nun altında olanlar hafif (grup 1), \%10-25 aras1 orta (grup 2), \%25-40 aras1 ağır (grup 3), \%40 üzeri çok ağır (grup 4) olarak gruplandırıldı. Diğer bir gruplandırma hastaneye başvuru anındaki GKS puanlarına göre idi. Hastalar GKS $=15$ puan olanlar (grup A) ve GKS $<15$ (grup B) puan olanlar şeklinde 2 gruba ayrıldı. Ayrıca hiperbarik oksijen tedavisi alan (grup I) ve almayan (grup II) hastalarda karş1laştırmalı olarak değerlendirildi.

\section{İstatistiksel Değerlendirme}

İstatistiksel analizde SPSS programı (IBM Corporation, Armonk, NY, USA) kullanıldı. Hasta verilerinin ortalama, minimum maksimum, standart sapma değerleri hesaplandi. Verilerin normalitesi Kolmogorov-Smirnov testi ile belirlendi. $\mathrm{p}<0.05$ olanlar için nonparametrik The Kruskal-Wallis testi yapıldı, gruplar arası ikili karş1laştırma da Mann Whitney $U$ test kullanıld1. $p>0.05$ olanlar için parametric One Way Analysis of Variance (ANOVA) testi analizi uyguland. $\mathrm{COHb}$ seviyelerine göre belirlenen gruplarını karşılaştırmasında kan ph değerleri için One Way Analysis of Variance (ANOVA) testi, Tukey Multiple Comparisons test kullanıldı, diğer parametrelerin analizi The Kruskal-Wallis test ile yapıldı, gruplar arası ikili karşılaştırma da Mann Whitney U test kullanıldı. GKS değerlerine göre belirlenen grupların karşılaştırmasında Mann Whitney U test kullanıldı. Hiperbarik oksijen tedavisi gereksinimine göre belirlenen grupların karşılaştırmasında Mann Whitney U test kullanıldı. Hasta verileri arasındaki ilişki incelemesinde Bivariate Corelation test ve Pearson Correlation test kullanıldı. İstatistiksel değerlendirme sonuçları $\mathrm{p}$ değeri $<0.05$ anlamlı kabul edildi.

\section{Bulgular}

Retrospektif çalışmamızdaki demografik verilere bakıldığında hastaların 32'si kadın, 31 'i erkek olup yaş ortalaması 44.5 yıl ( $\mathrm{SD}=$ 21.8 idi) idi. CO maruziyeti sonras1 acil servise başvuru süresi ortalama 6.22 saat idi. 
Başvuru anında $\mathrm{COHb}$ değerleri ortalama $\% 27(\mathrm{SD}=10.7)$ saptand. En s1k maruziyetin \%61.9 oranında kış mevsiminde olduğu saptandı. En sık maruziyeti kaynağının \% 93.7 oranında soba olduğu görüldü (Tablo 1-2).

Tablo 1. Hasta Verilerinin Ortalama, Standart Sapma, Minimum ve Maksimum Değerleri

\begin{tabular}{|c|c|c|c|c|c|}
\hline & n & Ortalama & Std D & Minimum & Maximum \\
\hline Yaş & 63 & 44,49 & 21,79 & 18,00 & 95,00 \\
\hline Acile Başvuru Süresi & 63 & 6,22 & 9,17 & 1,00 & 72,00 \\
\hline Geliș COHb & 63 & 27,00 & 10,68 & 0,30 & 50,00 \\
\hline Geliş GKS & 62 & 14,13 & 2,16 & 3,00 & 15,00 \\
\hline Çıkış GKS & 62 & 15,00 & 0 & 15,0 & 15,0 \\
\hline Hastanede Yatıș Günü & 63 & 1,71 & 0,86 & 1,00 & 6,00 \\
\hline
\end{tabular}

Tablo 2. Hasta Verilerinin Frekans ve Yüzde Değerleri

\begin{tabular}{|c|c|c|c|}
\hline & & Frekans & Yüzde \\
\hline \multirow[t]{2}{*}{ Cinsiyet } & Kadın & 32 & 50.8 \\
\hline & Erkek & 31 & 49.2 \\
\hline \multirow{3}{*}{ COHb Kaynağı } & Soba & 59 & 93.7 \\
\hline & Şofben & 3 & 4.8 \\
\hline & Benzin & 1 & 1.6 \\
\hline \multirow[t]{4}{*}{ Mevsim } & İlkbahar & 18 & 28.6 \\
\hline & Yaz & 1 & 1.6 \\
\hline & Sonbahar & 5 & 7.9 \\
\hline & Kiș & 39 & 61.9 \\
\hline \multirow[t]{2}{*}{ Geliş GKS } & 15 & 44 & 69.8 \\
\hline & 15 İn Alt1 & 18 & 28.6 \\
\hline \multirow[t]{2}{*}{ KVS Semptom } & Yok & 56 & 88.9 \\
\hline & Var & 7 & 11.1 \\
\hline \multirow[t]{2}{*}{ Nörolojik Semptom } & Yok & 13 & 20.6 \\
\hline & Var & 50 & 79.4 \\
\hline \multirow[t]{2}{*}{ Solunum Sistemi Semptom } & Yok & 48 & 76.2 \\
\hline & Var & 15 & 23.8 \\
\hline \multirow[t]{2}{*}{ GISS Semptom } & Yok & 40 & 63.5 \\
\hline & Var & 23 & 36.5 \\
\hline \multirow[t]{2}{*}{ Otolojik Semptom } & Yok & 53 & 84.1 \\
\hline & Var & 10 & 15.9 \\
\hline \multirow[t]{2}{*}{ Anormal EKG Bulgusu } & Yok & 53 & 84.1 \\
\hline & Var & 8 & 12.7 \\
\hline \multirow[t]{6}{*}{ İlk Semptom } & $\begin{array}{l}\text { Bulant1, } \\
\text { Kusma }\end{array}$ & 6 & 9.5 \\
\hline & Baș Ağrısı & 17 & 27.0 \\
\hline & Baş Dönmesi & 8 & 12.7 \\
\hline & Bilinç & 12 & 19.0 \\
\hline & $\begin{array}{l}\text { Bulanıklığ1 } \\
\text { Senkop }\end{array}$ & 19 & 30.2 \\
\hline & Konvülziyon & 1 & 1.6 \\
\hline \multirow[t]{2}{*}{ MV İhtiyacı } & Yok & 61 & 96.8 \\
\hline & Var & 2 & 3.2 \\
\hline \multirow[t]{2}{*}{ NIMV İhtiyacı } & Yok & 6 & 9.5 \\
\hline & Var & 57 & 90.5 \\
\hline \multirow[t]{2}{*}{ HBO İhtiyacı } & Yok & 51 & 81.0 \\
\hline & Var & 12 & 19.0 \\
\hline
\end{tabular}

COHb: karboksihemoglobin, GKS: Glaskow Koma Skalast, KVS: kardiyovasküler siste, GíS: gastrointestinal,

EKG: elektrokardiyografi, MV: mekanik ventilasyon, NIMV: noninvaziv mekanik ventilasyon, HBO: hiperbarik oksijen

Acil servise başvuru anında $44 \quad(\% 69.8)$ hastanın GKS puanının 15 olduğu ve 18 (\%28.6) hastanın ise GKS puanının 15 puanın altında olduğu ve tüm hastalar için ortalama GKS puanının $14.13 \quad(\mathrm{SD}=2.16) \quad$ olduğu saptandi. Hastaların 50'sinde (\%79.4) nöropsikiyatrik semptomlar (başağrısı, bilinç bulanıklığı, konvulziyon), 23'ünde (\%36.5) gastrointestinal sistem semptomlar (bulant1, kusma), 15'inde (\%23.8) solunum sistemi semptomlar1 (dispne), 10'unda (\%15.9) tanesinde otolojik semptomlar (kulak 
çınlaması, baş dönmesi), yedisinde (\%11.1) tanesinde ise KVS semptomları (çarpıntı) mevcuttu. $\mathrm{CO}$ maruziyeti olan hastaların sekizinde (\%12.7) EKG anormalliği (taşikardi, aritmi, ST depresyonu) saptand (Tablo 2).

Hastaların tedavisi esnasında iki hastada mekanik ventilatör, 57 hastada noninvazif mekanik ventilatör (NIMV) ihtiyacı ve 12 hastada hiperbarik oksijen (HBO) tedavisi ihtiyacı oldu (Tablo 2). Hastaların çıkış GKS değerleri ortalama $15(\mathrm{SD}=0,00)$ saptand. Hastaların hastanede ortalama yatış süreleri ise $1.71(\mathrm{SD}=0.86)$ gün bulundu (Tablo 1).
Hastalar başvuru anındaki $\mathrm{COHb}$ düzeylerine göre dört gruba ayrıldı. $\mathrm{COHb}$ düzeyi $\% 10$ 'nun altinda olanlar hafif (grup 1), \%1025 arası orta (grup 2), \%25-40 aras1 ağır (grup 3), \%40 üzeri çok ağır (grup 4) olarak gruplandırıldı. Gruplar arasinda $\mathrm{pH}(\mathrm{p}=0.048)$, GKS geliş puanı $(\mathrm{p}=0.006)$, otolojik semptomlar $\quad(\mathrm{p}=0.009), \quad$ NIMV ihtiyac1 $(\mathrm{p}=0.004), \mathrm{SpO} 2(\mathrm{p}=0.045), \mathrm{CK} \quad(\mathrm{p}=0.013)$, CKMB ( $=0.009)$ düzeyi değerleri arasında istatistiksel olarak anlamlı fark bulundu (Tablo 3).

Tablo 3. Hasta Laboratuvar Verilerinin Ortalama, Standart Sapma, Minimum ve Maksimum Değerleri

\begin{tabular}{|c|c|c|c|c|c|}
\hline & $\mathbf{n}$ & Ortalama & Std. S & Minimum & Maximum \\
\hline pH & 62 & 7.43 & 0.07 & 7,10 & 7,60 \\
\hline pCO2 & 62 & 31.31 & 6.45 & 17,90 & 43,00 \\
\hline pO2 & 62 & 123.01 & 39.80 & 48,00 & 288,00 \\
\hline $\mathbf{H b}$ & 62 & 14.01 & 2.07 & 7,90 & 17,80 \\
\hline Satürasyon & 62 & 96.08 & 7.19 & 53,00 & 99,40 \\
\hline CK & 62 & 229.74 & 449,30 & 33,00 & 2574,00 \\
\hline СКМB & 62 & 45.50 & 61,13 & 10,00 & 448,00 \\
\hline Troponin & 62 & 2.47 & 7,76 & 0,01 & 56,00 \\
\hline Laktat & 63 & 1.21 & 0,59 & 0,47 & 3,90 \\
\hline
\end{tabular}

Grupların ikili karşılaştırmalarında ph değerleri bakımından grup 2 ile grup 4 grupları arasında istatistiksel olarak anlamlı fark bulundu $(\mathrm{p}=0.048)$. GKS geliș puanları bakımından grup 1 ile grup $4(\mathrm{p}=0.011)$, grup 2 ile grup $4(\mathrm{p}=0.003)$ ve grup 3 ile grup 4 $(\mathrm{p}=0.024)$ grupları arasinda anlamlı fark bulundu. Otolojik semptomlar bakımından grup 1 ile grup $2(\mathrm{p}=0.022)$, grup 2 ile grup 4 $(\mathrm{p}=0.002)$ ve grup 3 ile grup $4(\mathrm{p}=0.014)$ grupları arasında istatistiksel olarak fark tespit edildi. NIMV değerleri bakımından grup 1 ile grup $2(\mathrm{p}=0.004)$ ve grup 1 ile grup 3 $(\mathrm{p}=0.007)$ grupları arasında istatistiksel olarak anlamlı fark vard1. SpO2 düzeyi değerleri ise grup 1 ile grup 3 grupları arasında faklıydı $(\mathrm{p}=0.015)$. Serum $\mathrm{CK}$ ve $\mathrm{CKMB}$ düzeyleri açısından grup 1 ile grup 4, grup 2 ile grup 4 ve grup 3 ile grup 4 grupları arasında istatistiksel olarak anlamlı fark vard $1(\mathrm{p}<0.05)$ (Tablo 4 ).

Tablo 4. COHB Düzeyine Göre Oluşturulan Grupların Ortalama, Minimum, Maksimum Değerleri, Gruplar Arası Karşılaştırma Sonuçları

\begin{tabular}{|c|c|c|c|c|c|c|c|}
\hline & $\mathrm{pH}^{*}$ & $\begin{array}{c}\text { GKS } \\
\text { Geliş** }\end{array}$ & Otolojik** & NIMV*** & SAT $* *$ & $\mathrm{CK}^{* *}$ & CKMB** \\
\hline Grup-1 & $\begin{array}{c}7,44 \\
(7,39-7,50)\end{array}$ & $\begin{array}{c}15,00 \\
(15-15)^{\mathbf{B}}\end{array}$ & $\begin{array}{c}1,33 \\
(1,00-2,00)^{\mathbf{E}}\end{array}$ & $\begin{array}{c}0,50 \\
(0,00-1,0)^{\mathbf{H}, \mathbf{I}}\end{array}$ & $\begin{array}{c}89,86 \\
(53,0-98,0)^{\mathbf{J}}\end{array}$ & $\begin{array}{c}73,00 \\
(33,00-111,0)^{\mathbf{K}}\end{array}$ & $\begin{array}{c}20,50 \\
(10,00-43,00)^{N}\end{array}$ \\
\hline Grup-3 & $\begin{array}{c}7,43 \\
(7,21-7,60)\end{array}$ & $\begin{array}{l}14,08 \\
(7-15)\end{array}$ & $\begin{array}{c}1,13 \\
(1,00-2,00)^{\mathbf{G}}\end{array}$ & $\begin{array}{c}0,92 \\
(0,00-1,0)^{\mathbf{I}}\end{array}$ & $\begin{array}{c}97,52 \\
(85,6-99,4)^{\mathbf{J}}\end{array}$ & $\begin{array}{c}169,30 \\
(44,0-1330,0)^{\mathbf{M}}\end{array}$ & $\begin{array}{c}36,94 \\
(12,00-185,00)^{\mathbf{P}}\end{array}$ \\
\hline p değeri & 0.048 & 0.006 & 0.009 & 0.004 & 0.045 & 0.013 & 0.009 \\
\hline
\end{tabular}




\begin{tabular}{|c|c|c|c|}
\hline $\mathbf{A}$ & grup 2 ile grup 4 arasında (p:0,028), & $\mathbf{I}$ & grup 1 ile grup 3 arasında (p:0,007), \\
\hline B & grup 1 ile grup 4 arasında (p:0,011), & $\mathrm{J}$ & grup 1 ile grup 3 arasında (p:0,015), \\
\hline C & grup 2 ile grup 4 arasında (p:0,003), & $\mathrm{K}$ & grup 1 ile grup 4 arasında (p:0,006), \\
\hline D & grup 3 ile grup 4 arasında (p:0,024), & $\mathrm{L}$ & grup 2 ile grup 4 arasında (p:0,010), \\
\hline $\mathbf{E}$ & grup 1 ile grup 2 arasında (p:0,022), & M & grup 3 ile grup 4 arasında (p:0,007), \\
\hline $\mathbf{F}$ & grup 2 ile grup 4 arasında (p:0,002), & $\mathrm{N}$ & grup 1 ile grup 4 arasında (p:0,011), \\
\hline G & grup 3 ile grup 4 arasında (p:0,014), & $\mathrm{O}$ & grup 2 ile grup 4 arasında (p:0,021), \\
\hline $\mathbf{H}$ & grup 1 ile grup 2 arasında (p:0,004), & $\mathrm{P}$ & grup 3 ile grup 4 arasinda (p:0,004). \\
\hline
\end{tabular}

pH: potansiyel hidrojen GKS: Glaskow Koma Skalası NIMV: Noninvaziv mekanik ventilasyon SAT: satürasyon pCO2: parsiyel karbondioksit basincı CK: kreatin kinaz CKMB: kreatin kinaz $m b *$ ANOVA testi kullanıldı $\mathrm{p}<0,05$ anlamlı kabul edildi.

** Kruskal-Wallis Test kullanıldı, gruplar arası ikili karşılaştırma Mann-Whitney Test ile yapıldı p<0,05 anlamlı kabul edildi

Hastaların hastaneye başvuru anındaki GKS puanlarına bakıldığında grup A ve grup B grupları arasında; $\mathrm{COHb}$ geliş düzeyi $(\mathrm{p}=0.006), \quad \mathrm{KVS}$ semptomlarının varlı $\mathrm{g} 1$ $(\mathrm{p}=0.009)$, ek hastalı varlığ $(\mathrm{p}=0.036)$, solunum sistemi semptomları varlı̆̆ $(\mathrm{p}=0.018)$, mekanik ventilatör ihtiyac1 $(\mathrm{p}=0.026)$, HBO ihtiyac1 $(\mathrm{p}<0.001), \quad \mathrm{CK}$ düzeyi $(\mathrm{p}=0.006)$ ve troponin düzeyi $(\mathrm{p}=0.025)$ açısından istatistiki olarak anlamlı fark bulundu. (Tablo 5).

Tablo 5. GKS Puanlarına Göre Oluşturulan Grupların Mann-Whitney Testi ile Karşılaştırma Sonuçları

\begin{tabular}{|c|c|c|c|c|c|c|c|c|c|}
\hline & $\begin{array}{c}\mathrm{COHb} \\
\text { Geliş }\end{array}$ & İlk Semptom & KVS & Ek Hastalık & Solunum & $\begin{array}{c}\text { MV } \\
\text { İhtiyacı }\end{array}$ & $\mathrm{HBO}$ & $\mathrm{CK}$ & $\begin{array}{c}\text { Tropon } \\
\text { in }\end{array}$ \\
\hline Grup A & $\begin{array}{l}24,59 \\
(0,30- \\
50,00)\end{array}$ & $\begin{array}{c}3,36 \\
(1,00-6,00)\end{array}$ & $\begin{array}{c}1,04 \\
(1,00-2,00)\end{array}$ & $\begin{array}{c}0,23 \\
(0-1,00)\end{array}$ & $\begin{array}{c}1,15 \\
(1,00-2,00)\end{array}$ & $\begin{array}{c}0,00 \\
(0)\end{array}$ & $\begin{array}{c}0,07 \\
(0- \\
1,00)\end{array}$ & $\begin{array}{l}100,81 \\
(33,00- \\
277,00)\end{array}$ & $\begin{array}{c}2,13 \\
(0,01- \\
56,00)\end{array}$ \\
\hline Grup B & $\begin{array}{c}32,60 \\
(15,40- \\
50,00)\end{array}$ & $\begin{array}{c}4,06 \\
(1,00-5,00)\end{array}$ & $\begin{array}{c}1,27 \\
(1,00-2,00)\end{array}$ & $\begin{array}{c}0,50 \\
(0-1,00)\end{array}$ & $\begin{array}{c}1,44 \\
(1,00-2,00)\end{array}$ & $\begin{array}{c}0,11 \\
(0-1,00)\end{array}$ & $\begin{array}{c}0,50 \\
(0- \\
1,00)\end{array}$ & $\begin{array}{c}544,88 \\
(58,00- \\
2574,00)\end{array}$ & $\begin{array}{c}3,32 \\
(0,10- \\
21,20)\end{array}$ \\
\hline$P$ değeri & 0,006 & 0,045 & 0,009 & 0,036 & 0,018 & 0,026 & $\begin{array}{c}0,00 \\
0\end{array}$ & 0,006 & 0,025 \\
\hline
\end{tabular}

COHb: karboksihemoglobin KVS: kardiyovasküler MV: mekanik ventilasyon HBO: hiperbarik oksijen tedavisi

CK: kreatin kinaz $p<0,05$ anlaml kabul edildi.

Tüm hastalar için yaş ile yatış günleri arasında pozitif yönde korelasyon vardı. Yaş ile PO2 arasında negatif yönde korelasyon vardı. Hastaların yaşı arttıkça hastanede kalış süresi uzarken kan PO2 değerlerinin de azaldığ düşünüldü. Diğer yandan hastaneye başvuru anındaki $\mathrm{COHb}$ değerleri ile serum $\mathrm{CK}$ ve $\mathrm{CKMB}$ değerleri arasında pozitif, $\mathrm{COHb}$ değerleri ile GKS puanları arasında negatif korelasyon olduğu görüldü. GKS puanları ile serum CK düzeyi, serum troponin düzeyleri, NIMV ve HBO gereksinimi arasında negatif korelasyon olduğu görüldü. Arteryel kan ph değeri ile $\mathrm{PCO} 2$ değeri, serum troponin düzeyi ve NIMV ihtiyac1 arasinda negatif korelasyon bulundu. Serum CK düzeyi ile serum CKMB düzeyi, laktat düzeyi, mekanik ventilatör desteği ihtiyacı ve HBO ihtiyac1 arasında pozitif korelasyon olduğu saptandı. Serum CKMB düzeyi ile NIMV ihtiyacı arasında, serum troponin düzeyi ile laktat düzeyi ve HBO ihtiyacı arasinda ve NIMV ihtiyac1 ile HBO ihtiyaci arasında pozitif korelasyon bulundu (Tablo 6). 
Tablo 6. Bivariate Corelation Test, Pearson Correlation Test Analizi Sonuçları

\begin{tabular}{|c|c|c|c|c|c|c|c|c|c|c|c|c|c|c|c|c|c|c|c|}
\hline & & Yaş & Cins & $\mathrm{COHb}$ & GKS & PH & pCO2 & pO2 & SAT & Hgb & CK & CKMB & Trop & $\begin{array}{c}\text { Lak } \\
\text { tat }\end{array}$ & MV & NIMV & HBO & Gün & Acil \\
\hline \multirow[t]{2}{*}{ Yaş } & $\mathrm{r}$ & 1.000 & -0.217 & -0.045 & -0.051 & 0.002 & -0.128 & -0.317 & -0.221 & -0.279 & -0.110 & -0.073 & -0.100 & 0.077 & 0.227 & 0.153 & 0.077 & 0.266 & 0.218 \\
\hline & $\mathrm{p}$ & & 0.087 & 0.724 & 0.691 & 0.988 & 0.323 & 0.012 & 0.084 & 0.028 & 0.396 & 0.572 & 0.438 & 0.548 & 0.074 & 0.231 & 0.550 & 0.035 & 0.086 \\
\hline \multirow{2}{*}{ Cins } & $\mathrm{r}$ & & 1.000 & 0.115 & -0.054 & -0.159 & 0.024 & 0.081 & 0.165 & 0.581 & 0.282 & 0.194 & 0.188 & -0.004 & 0.184 & 0.103 & 0.169 & -0.124 & -0.024 \\
\hline & $\mathrm{p}$ & & & 0.368 & 0.676 & 0.217 & 0.851 & 0.531 & 0.199 & $<0.001$ & 0.026 & 0.131 & 0.144 & 0.973 & 0.149 & 0.422 & 0.184 & 0.331 & 0.853 \\
\hline $\mathrm{COHb}$ & $\mathrm{p}$ & & & & 0.001 & 0.210 & 0.305 & 0.124 & 0.128 & 0.901 & 0.010 & 0.004 & 0.471 & 0.393 & 0.028 & 0.290 & 0.100 & 0.669 & 0.284 \\
\hline \multirow[t]{2}{*}{ GKS } & $\mathrm{r}$ & & & & 1.000 & 0.135 & 0.142 & -0.156 & -0.175 & $\begin{array}{l}-0.095 \\
\end{array}$ & -0.397 & $\begin{array}{l}-0.169 \\
\end{array}$ & -0.308 & -0.234 & -0.380 & -0.186 & -0.536 & -0.037 & 0.116 \\
\hline & $\mathrm{p}$ & & & & & 0.294 & 0.269 & 0.227 & 0.172 & 0.464 & 0.001 & 0.190 & 0.015 & 0.067 & 0.002 & 0.147 & $<0.001$ & 0.773 & 0.370 \\
\hline \multirow[t]{2}{*}{ PH } & $\mathrm{r}$ & & & & & 1.000 & -0.364 & -0.047 & 0.123 & 0.017 & -0.166 & -0.136 & -0.272 & -0.173 & -0.307 & -0.010 & -0.209 & 0.001 & -0.083 \\
\hline & $\mathrm{p}$ & & & & & & 0.004 & 0.715 & 0.341 & 0.896 & 0.196 & 0.292 & 0.032 & 0.179 & 0.015 & 0.939 & 0.103 & 0.994 & 0.519 \\
\hline $\mathrm{pCO} 2$ & $\mathrm{r}$ & & & & & & 1.000 & -0.391 & -0.522 & 0.007 & -0.123 & 0.025 & 0.169 & -0.003 & -0.013 & -0.005 & 0.017 & -0.033 & -0.089 \\
\hline \multirow[t]{2}{*}{ pO2 } & $\mathrm{r}$ & & & & & & & 1.000 & 0.606 & 0.150 & 0.133 & 0.053 & -0.107 & -0.093 & -0.026 & -0.118 & -0.023 & 0.037 & -0.079 \\
\hline & $\mathrm{p}$ & & & & & & & & $<0.001$ & 0.244 & 0.303 & 0.682 & 0.410 & 0.473 & 0.844 & 0.363 & 0.860 & 0.776 & 0.541 \\
\hline \multirow[t]{2}{*}{ SAT } & $\mathrm{r}$ & & & & & & & & 1.000 & 0.125 & 0.135 & 0.024 & -0.076 & -0.163 & -0.098 & 0.013 & -0.123 & -0.069 & -0.083 \\
\hline & $\mathrm{p}$ & & & & & & & & & 0.334 & 0.297 & 0.855 & 0.555 & 0.206 & 0.451 & 0.918 & 0.341 & 0.593 & 0.523 \\
\hline \multirow[t]{2}{*}{$\mathrm{Hgb}$} & $\mathrm{r}$ & & & & & & & & & 1.000 & 0.356 & 0.246 & 0.094 & 0.053 & 0.051 & 0.159 & 0.186 & -0.002 & -0.218 \\
\hline & $\mathrm{p}$ & & & & & & & & & & 0.005 & 0.054 & 0.468 & 0.681 & 0.694 & 0.217 & 0.148 & 0.986 & 0.088 \\
\hline \multirow[t]{2}{*}{ CK } & $\mathrm{r}$ & & & & & & & & & & 1.000 & 0.589 & 0.152 & 0.334 & 0.286 & 0.223 & 0.274 & 0.008 & -0.074 \\
\hline & $\mathrm{p}$ & & & & & & & & & & & $<0.001$ & 0.237 & 0.008 & 0.024 & 0.081 & 0.031 & 0.953 & 0.570 \\
\hline \multirow[t]{2}{*}{ CKMB } & $\mathrm{r}$ & & & & & & & & & & & 1.000 & 0.050 & 0.195 & 0.276 & 0.124 & 0.179 & 0.003 & -0.019 \\
\hline & $\mathrm{p}$ & & & & & & & & & & & & 0.700 & 0.129 & 0.030 & 0.336 & 0.163 & 0.980 & 0.886 \\
\hline \multirow[t]{2}{*}{ Trop } & $\mathrm{r}$ & & & & & & & & & & & & 1.000 & 0.344 & 0.232 & -0.015 & 0.312 & -0.036 & 0.033 \\
\hline & $\mathrm{p}$ & & & & & & & & & & & & & 0.006 & 0.070 & 0.908 & 0.014 & 0.781 & 0.800 \\
\hline \multirow[t]{2}{*}{ MV } & $\mathrm{r}$ & & & & & & & & & & & & & & 1.000 & 0.059 & 0.373 & -0.036 & 0.216 \\
\hline & $\mathrm{p}$ & & & & & & & & & & & & & & & 0.647 & 0.003 & 0.782 & 0.090 \\
\hline \multirow[t]{2}{*}{ NIMV } & $\mathrm{r}$ & & & & & & & & & & & & & & & 1.000 & 0.157 & 0.099 & -0.031 \\
\hline & p & & & & & & & & & & & & & & & & 0.218 & 0.438 & 0.807 \\
\hline \multirow[t]{2}{*}{$\mathrm{HBO}$} & $\mathrm{r}$ & & & & & & & & & & & & & & & & 1.000 & .102 & 0.039 \\
\hline & $\mathrm{p}$ & & & & & & & & & & & & & & & & & .424 & 0.760 \\
\hline \multirow[t]{2}{*}{ Gün } & $\mathrm{r}$ & & & & & & & & & & & & & & & & & 1.000 & 0.000 \\
\hline & $\mathrm{p}$ & & & & & & & & & & & & & & & & & & 1.000 \\
\hline Acil & $\mathrm{r}$ & & & & & & & & & & & & & & & & & & 1.000 \\
\hline
\end{tabular}

$n$ : hasta saylsl, GKS: Glaskow Koma Skalasl , pCO2: parsiyel karbondioksit basincl, pO2: parsiyel oksijen basincl, SAT: satürasyon, Hgb: hemoglobin, CK: kreatin kinaz

CKMB: kreatin kinaz mb, MV: mekanik ventilasyon, HBO: hiperbarik oksijen, NIMV: noninvaziv mekanik ventilasyon 
Ayrica HBO tedavisi alan hastalarda (grup I) troponin-I $\quad(\mathrm{p}=0,015), \quad \mathrm{CK}(\mathrm{p}=0,032)$ düzeylerinde ve mekanik ventilasyon ihtiyacında $(\mathrm{p}=0,003)$ belirgin artış olduğu, glaskov skorlarının düşük olduğu $(\mathrm{p}<0,001)$ tespit edildi. Bununla birlikte HBO tedavisi gereksinimi ile troponin ve CK seviyesi arasında pozitif yönde korelasyon olduğu görüldü ( Tablo 7).

Tablo 7. HBO Gereksinimine Göre Gruplar Arası Karşılaştırma

\begin{tabular}{lcccc}
\hline \multicolumn{4}{c}{ HBO Gereksinimine Göre Karşılaştırma } \\
\hline \multirow{2}{*}{ Troponin I } & & Grup I & Grup II & p \\
CK & & $155,50( \pm 656,62)$ & $0,16( \pm 8,44)$ & 0,015 \\
Glaskov & & $13,50( \pm 3,95)$ & $15,00 \pm( \pm 0,78)$ & $<0,001$ \\
MV ihtiyacı & Var & $2(\% 16,7)$ & 0 & 0,003 \\
& Yok & $10(\% 83,3)$ & $51(\% 100)$ & \\
\hline
\end{tabular}

\section{Tartışma}

Retrospektif çalışmamızda hastalarımızın GKS'1 düştükçe ve $\mathrm{COHb}$ değerleri yükseldikçe mekanik ventilatör ve $\mathrm{HBO}$ ihtiyaçları artmaktadır. Bu durumun hastaların yoğun bakım takiplerinde tedavi süreci ve prognozuna olumsuz bir şekilde yansıdığını görmekteyiz.

Kaza ile olan COİ daha çok soğuk iklimlerde ve kış aylarında görülürken intihar amaçlı zehirlenmeler yıl boyunca eşit dağılım göstermektedir (3-5). Bizim çalışmamızda da literatür ile benzerlik göstermekle beraber hastalarımızın hepsi kazara olan zehirlenmelerdi. $\mathrm{Bu}$ mevsimsel dağılıma ülkemizde uzun süren soğuk havanın ve ısınma ihtiyacını karşılamaya yönelik kullanılan sobanın etken olduğu düşünüldü. Maruziyet kaynakları incelendiğinde COİ 'da kaynağın çoğunlukla evlerde yakılan sobalardan sızan $\mathrm{CO}$ gazı olduğu bilinmektedir (6).

Patrick ve ark yaptıkları bir çalışmada COİ ile gelen 1006 hastanın \%54'nün kadın ve yaş ortalamalarının $\quad 30 \pm 20$ y1l olduğunu bildirmişlerdir (1). Bizim çalışmamızda da hastalarımızın \%50,8'i kadın idi. Hastaların ortalama yaş1 44,49 idi. Bu değerler literatürle uyumlu görünmekle beraber yaş ortalamasının yüksekliğini bölgesel olarak ileri yaş popülasyonun düşük sosyoekonomik faktörler ile ilişkisi ile açıklayabiliriz. Klinik belirtilerin ciddiyeti $\mathrm{CO}$ gazına maruziyet süresi ile yakından ilişkilidir (7-9). Bizim hastalarımızın acil servise başvuru anında $\mathrm{COHb}$ değerleri ortalama $\% 27$ iken maruziyeti sonrasi acil servise başvuru ortalama süresi ise $6,22( \pm 9.17)$ saat idi. Başvuru süresindeki gecikmenin başvuru anındaki ortalama $\mathrm{COHb}$ yüksekliğini yansıtmış olduğunu düşünmekteyiz.

COİ en önemli etkilerini santral sinir sistemi ve kardiyovasküler sistem (KVS) üzerinde gösterdiği bilinmektedir (10-12). Bizim çalışmamızda literatür ile benzerlik göstermekle beraber ilk sirada senkopun, takiben baş ağrısının olmasının uzun maruziyet süresi sonucu ani yükselen $\mathrm{COHb}$ düzeylerine bağlı olabileceğini düşünmekteyiz.

COI'larında doku hipoksisine ve sitotoksisiteye bağlı asidoz ortaya çıtı̆̆ı ve kan ph düzeyinin düştügü ve laktat düzeyinin yükseldiği bilinmektedir. Buna karşın ağır hastalarda kan ph değeri daha düşük olduğu saptanmış olsa da, düşük kan ph değerinin ağır hastalıkla ilişkili olduğu gösterilememiştir. Ayrıca ağır vakalarda daha yüksek kan laktat düzeyleri gözlenirken, orta ve hafif zehirlenmelerde kan laktat düzeyinin normal sinırlarda kalma eğiliminde olduğu görülmüş fakat prognozu tayin etmede veya tedavi şeklini belirlemedeki rolü hakkında kesin bir sonuca varılamamıştır (13-15). İlaveten GKS skorunun hastanın klinik seyrini belirlemede değerli olduğu ortaya konulmuştur (16). Nitekim bizim çalışmamızda $\mathrm{COHb}$ düzeyi çok yüksek olan hastalarda GKS geliş puanlarının belirgin düşüş gösterdiği; $\mathrm{pH}$ değerlerinin asidoz tarafına kaydığı; CK ve CK-MB düzeylerinde 
ise artış olduğu gözlendi. Ayrıca korelasyon test sonuçlarına bakıldığında $\mathrm{COHb}$ düzeyleri arttıkça serum CK ve CKMB düzeylerinin arttığı, GKS puanlarının ise düştüğü görüldü.

Doğan ve ark(19) yapmış oldukları çalışmada laktat düzeylerinin $\mathrm{COHb}$ düzeylerine paralel olarak arttığı gösterilmiş, laktat düzeyinin $1,85 \mathrm{mmol} / \mathrm{l}$ olmasinın HBO tedavisi endikasyonu için \%70,8 sensitivite ve $\% 78,0$ spesitivite ile belirleyici olduğu öne sürülmüştür. Yelken $\mathrm{B}$ ve $\operatorname{ark}(17) \mathrm{COHb}$ seviyeleri ile QT aralığı, CK-MB, troponin-I seviyeleri arasında bir korelasyon bildirmişlerdir. Aslan ve $\operatorname{ark}(18)$ ise $\mathrm{COHb}$ seviyeleri ile CK, CK-MB seviyeleri arasında hiçbir korelasyon tespit etmemiştir. Bizim çalışmamızda korelasyon test sonuçlarına göre; GKS puanları düştükçe serum $\mathrm{CK}$ ve troponin düzeylerinde, mekanik ventilatör desteği ihtiyacında ve HBO ihtiyacında artış olduğu görüldü. $\mathrm{Bu}$ hastalarda kan ph değerindeki düşüşün $\mathrm{PCO} 2$ ve troponin değerinde artışa ve mekanik ventilatör ihtiyacında artışa yol açtığı görüldü. Ayrıca laktat değerleri arttıkça HBO ihtiyacının da arttığ1; yine serum CK değeri arttıkça serum CK-MB ve laktat düzeylerinde de artış olduğu, bunlarla beraber mekanik ventilasyon ihtiyacının ve HBO ihtiyacının da artış gösterdiği görüldü. Bunun yanında $\mathrm{COHb}$ düzeyleri ile $\mathrm{CK}(\mathrm{p} 0,013)$ ve CK-MB (p $0,009)$ düzeyleri arasında pozitif korelasyon bulundu fakat troponin-I düzeyleri açısından anlamlı bir korelasyon saptanmadı. İçme ve ark. yapmış oldukları çalışmada hem troponin-I hem de CK-MB düzeyleri artmış hastaların laktat düzeyleri daha yüksek olduğunu, ancak bu hastaların $\mathrm{COHb}$ düzeylerinin değişmediğini ve hastaların laktat seviyeleri ile troponin değerleri arasında korelasyon olduğunu bildirmişlerdir (20). Bizim hastalarımızda da literatürle uyumlu olarak CK değeri artarken CKMB ve laktat seviyelerinin de arttığı gözlendi. Ayrıca kan laktat düzeyleri ile troponin-I düzeyleri arasinda pozitif korelasyon bulundu.

Doku hipoksisi COİ'nun başlıca sonucudur. CO zehirlenmesi tedavisinin temelini karbonmonoksidi bağlı bulunduğu bölgelerden rekabetçi bir şekilde uzaklaştıran oksijenin kullanımı (solunum havasındaki oksijen konsantrasyonunun arttırilmasiyla veya atmosfer basıncının arttırılması) teşkil etmektedir $(21,22)$. Klinik belirtilerin olduğu ve şüpheli tüm vakalarda $\mathrm{O}_{2}$ desteği ile kan $\mathrm{COHb}$ eliminasyonu hızlanıp doku hipoksisi azaldığından dolayı maske ya da endotrakeal tüp ile yüksek akım $\mathrm{O}_{2}$ ile normobarik oksijen (NBO) desteği ilk basamak tedavidir $(1,3)$. Bu sayede $\mathrm{COHb}$ yarı ömrü ortalama 5 saatten 1 saate düşmektedir. Hayvan modellerinde ise 2.5 atm basınçta uygulanan hiperbarik oksijen tedavisinin (HBO) bu süreyi 20 dakikaya indirgeyebildiği tespit edilmiştir. Ancak literatürde COİ'larında HBO tedavisinin uygulanması için henüz objektif kriterler tanımlanmamış olmakla birlikte bu tedavinin düzenlenmesinde genellikle klinik bulgular (bilinç kaybı, nörolojik patoloji bulguları, kardiyak iskemi ve şiddetli asidoz gibi) ve $\mathrm{COHb}$ seviyeleri ön planda tutulmaktadır (2325). Diğer yandan İçme ve ark. yapmış oldukları bir çalışmada HBO tedavisi alan hastalarda $\mathrm{COHb}$, laktat, CK-MB ve troponinI düzeylerinin daha yüksek olduğunu bildirmişlerdir (20). Nitekim bizim hastalarımızda da literatür ile uyumlu bir şekilde HBO tedavisi alan hastalarda (grup I) troponin-I, CK düzeylerinde ve mekanik ventilasyon ihtiyacında belirgin artış olduğu, glaskow koma skorlarının düşük olduğu tespit edildi. Bununla birlikte HBO tedavisi gereksinimi ile troponin ve CK seviyesi arasında pozitif yönde korelasyon olduğu görüldü.

$\mathrm{Bu}$ çalışma sonunda COİ tanılı hastalarda başvuru anındaki GKS puanı, $\mathrm{COHb}, \mathrm{CK}$, CK-MB ve laktat düzeylerinin belirlenmesi ve bunların klinik bulgular ile birlikte yorumlanmasının hem tedavi süreçleri hem de prognoz üzerinde önemli etkilerinin olabileceği düşünüldü.

- $\quad$ Bu makale Türk Yoğun Bakım Derneği tarafindan düzenlenen 21th International Intensive Care Symposium 12-13 May 2017 / ISTANBUL' da poster olarak sunulmuştur. 


\section{KAYNAKLAR}

1. Partrick M, Fiesseler F, Shih R, Riggs R, Hung O: Monthly variations in the diagnosis of carbon monoxide exposures in the emergency department. Undersea \& Hyperbaric Medicine 2009; 36:161.

2. Kandis H, Katırcı Y, Çakır Z, Aslan S,, Uzkeser M, Bilir Ö: Acil servise karbon monoksit entoksikasyonu ile başvuran olguların geriye dönük analizi. Akademik Acil Tip Dergisi 2007; 5:21-25.

3. Elif D, Akgür SA, Oztürk P, Sen F: Fatal poisonings in the Aegean region of Turkey. Veterinary and human toxicology 2003;45:106-8.

4. Salameh S, Amitai Y, Antopolsky M, Rott D, Stalnicowicz R: Carbon monoxide poisoning in Jerusalem: Epidemiology and risk factors. Clinical toxicology 2009; 47:137-41.

5. İnal V: Karbonmonoksit Zehirlenmesi ve Tedavisi. Turkiye Klinikleri Journal of Anesthesiology Reanimation 2005; 3:34-41.

6. Lapresle J, Fardeau M: The central nervous system and carbon monoxide poisoning II. Anatomical study of brain lesions following intoxication with carbon monoxide (22 cases). Progress in brain research 1967 ; 24:31-74.

7. Keles A, Demircan A, Kurtoglu G: Carbon monoxide poisoning: how many patients do we miss? European Journal of Emergency Medicine 2008; 15:154-57.

8. Hampson NB, Hauff NM: Carboxyhemoglobin levels in carbon monoxide poisoning: do they correlate with the clinical picture? The American Journal of Emergency Medicine 2008; 26:665-9.

9. Chan MY, Au T, Leung KS, Yan WW: Acute carbon monoxide poisoning in a regional hospital in Hong Kong: historical cohort study. Hong Kong Medical Journal 2016; 22:46-55.

10. Salluh JI, Soares M: ICU severity of illness scores: APACHE, SAPS and MPM. Current Opinion in Critical Care 2014; 20(5):557-565.

11. Satar S. Acilde Klinik Toksikoloji. Nobel Kitabevi Adana 2009

12. Satran D, Henry CR, Adkinson C, Nicholson CI, Bracha Y, Henry TD: Cardiovascular manifestations of moderate to severe carbon monoxide poisoning. Journal of the American College of Cardiology 2005; 45:1513-16.

13. Moon JM, Shin MH, Chun BJ: The value of initial lactate in patients with carbon monoxide intoxication: in the emergency department. Human \& Experimental Toxicology 2011; 30:836-43.

14. Benaissa ML, Megarbane B, Borron SW, Baud FJ: Is elevated plasma lactate a useful marker in the evaluation of pure carbon monoxide poisoning? Intensive Care Medicine 2003, 29:1372-75.

15. Marchi AG, Renier S, Messi G, Barbone F: Childhood poisoning: a population study in Trieste, Italy, 1975-1994. Journal Of Clinical Epidemiology 1998; 51:687-95.

16. Teksam O, Gumus P, Bayrakci B, Erdogan I, Kale G: Acute cardiac effects of carbon monoxide poisoning in children. European Journal of Emergency Medicine 2010; 17:192-6.

17. Yelken B, Tanrıverdi B, Çetinbaș F, Memiș D, Süt $\mathrm{N}$ : The assessment of QT intervals in acute carbon monoxide poisoning. Anatolian Journal of Cardiology/Anadolu Kardiyoloji Dergisi 2009; 9:397-400

18. Aslan S, Erol MK, Karcioglu O, Meral M, Cakir $\mathrm{Z}$, Katirci Y: The investigation of ischemic myocardial damage in patients with carbon monoxide poisoning. The Anatolian journal of cardiology 2005; 5:189-93.

19. Dogan NO, Savrun A, Levent S, Gunaydin GP, Celik GK, Akkucuk H, Cevik Y: Can initial lactate levels predict the severity of unintentional carbon monoxide poisoning? Human \& Experimental Toxicology 2015; 34:324-9.

20. Icme F, Kozaci N, Ay M, Avci A, Gumusay U, Yilmaz M, Satar S: The relationship between blood lactate, carboxy-hemoglobin and clinical status in $\mathrm{CO}$ poisoning. European Review for Medical and Pharmacological Sciences 2014; 18:393-7.

21. Sen H: Karbonmonoksit Zehirlenmesi. TAF Preventive Medicine Bulletin 2009; 8:351-6.

22. İncekaya Y, Feyizi H, Bayraktar S, Ali İ, Topuz C, Karacalar S, Turgut N Karbonmonoksit Zehirlenmesi ve Hiperbarik Oksijen Tedavisi Okmeydanı Tip Dergisi 2017; 33:114-8.

23. Kandiş H, Katırcı Y, Karapolat B: Karbonmonoksit zehirlenmesi. Düzce Üniversitesi Tip Fakültesi Dergisi 2009; 11:54-60.

24. Prockop LD, Chichkova RI: Carbon monoxide intoxication: an updated review. Journal of The Neurological Sciences 2007; 262:122-30.

25. Hampson NB, Piantadosi CA, Thom SR, Weaver LK: Practice recommendations in the diagnosis, management, and prevention of carbon monoxide poisoning. American Journal Of Respiratory And Critical Care Medicine 2012; 186:1095-101. 